\title{
F2R wt Allele
}

National Cancer Institute

\section{Source}

National Cancer Institute. F2R wt Allele. NCI Thesaurus. Code C51443.

Human F2R wild-type allele is located within $5 q 13$ and is approximately $20 \mathrm{~kb}$ in length.

This allele, which encodes proteinase-activated receptor 1 protein, is involved in the regulation of the thrombotic response. 